\title{
The effect of pasture buffer length and pasture type on runoff water quality following prescribed burning in the Wivenhoe Catchment
}

\author{
H. Ghadiri ${ }^{A}$, J. Hussein ${ }^{A B}$, and C.W. Rose ${ }^{A}$ \\ ${ }^{A}$ Environmental Futures Centre, Griffith University, Nathan, QLD 4111, Australia. \\ ${ }^{* B}$ Corresponding author. Email: janethussein@ bigpond.com.
}

\begin{abstract}
Burning of pastures is a management practice adopted by graziers worldwide. When rain falls on burnt pastures, this can lead to increased pollutant transport in runoff. However, this transport can be modified by vegetative buffers which intercept the runoff downslope of burnt areas. This study examines the effects of different pasture buffer lengths $(0,2$ and $5 \mathrm{~m})$ on sediment and chemical transport from two pasture sites near Wivenhoe Dam, the main water reservoir for Brisbane City. Simulated rainfall $(100 \mathrm{~mm} / \mathrm{h})$ was applied to 18 plots on pasture sites after they were burnt and insoluble and soluble components were measured in the runoff. Most eroded sediment/organic debris accumulated against the first row of the grass buffer strips or was deposited in the upslope backwater region. Buffer length had little impact on the runoff concentration of $\mathrm{NO}_{\mathrm{x}}$, total Kjeldahl nitrogen (TKN) and total nitrogen $(\mathrm{TN})$ from the $5 \mathrm{~m}$-length upslope plots but was significant for sediment loss rate (SLR), filterable reactive phosphate (FRP), ammonium $\left(\mathrm{NH}_{4}{ }^{+}\right)$, total and dissolved organic carbon (TOC; DOC). Pasture type was significant for $\mathrm{NO}_{\mathrm{x}} \mathrm{NH}_{4}{ }^{+}, \mathrm{SLR}$ and TOC only. Burning increased enrichment ratios (ER) of nutrients and carbon in the runoff compared to unburnt plots but a $2 \mathrm{~m}$ buffer strip subsequently reduced the ER values by $>30 \%$. Buffers strips of unburnt pasture grass may provide an effective tool for post-fire erosion control following prescribed burning but further work including scaling to larger plot sizes and catchment level is required.
\end{abstract}


Keywords: Post-fire erosion control, buffer strip, sediment loss, pasture burning; nutrient loss;

\section{Introduction}

Burning of pasture is commonly practised in many parts of the world for its perceived ability to improve pasture quality and palatability, reduce woody shrubs, control weeds and increase nutrient supply (see for example Svejcar 1989; Orr and Paton 1997) However, burning is known to affect soil erodibility and runoff quality (DeBano et al. 1998; Johansen et al. 2001; Burke et al. 2005; Llovet et al. 2008). Water reservoirs in many areas are surrounded by pastures, so when burning is followed by rainfall, this causes runoff pollutants such as sediment, nutrients and carbon to enter the water and affect water quality. The intensity of the burning affects the type and amount of ash produced and also the properties of the underlying soil (Dragovich and Morris 2002; Coelho et al. 2004; Llovet et al. 2008) which both have implications for the amount of runoff and sediment loss (Robichaud and Waldrop 1994; Benavides-Solorio et al. 2004).

Vegetative buffer strips have been widely employed in catchments of water-supply reservoirs to reduce fluxes of pollutants which may affect water quality. Their effectiveness in mitigating pollutant transport in overland flow has been the subject of extensive research (see for example Meyer et al. 1995; Ghadiri et al. 2001; Rose et al. 2003; Blanco-Canqui et al. 2004; Hussein et al. 2007, 2008). There are potentially a number of variables which can influence sediment-trapping efficiency of buffers, including the type of vegetation used, the length of the buffer, sediment type, hydraulic load, flow rate and topography. Several studies have shown that stiff grass buffers (hedges) as narrow as $20 \mathrm{~cm}$ are very effective in trapping sediment (Dabney et al. 1995). Shorter, less rigid vegetation such as pasture grasses, are less 
effective in trapping sediment (Meyer et al. 1995) and longer buffer widths may be required to reduce fluxes of pollutants (Gharabaghi et al. 2002). However, it has also been reported that large increases in length of grass barriers do not always result in substantial increases in sediment trapping efficiency of the barriers (Ghadiri et al. 2001; Blanco-Canqui et al. 2004).

While there is some data on runoff from Australian landscapes following burning, much of this is relates to sediment loss from forested areas (see for example Prosser and Williams 1997; Dragovich et al. 2002 and Lane et al. 2006). There is less information on losses of sediment, nutrients and carbon from burned pastures or on enrichment of sediment-sorbed contaminants in runoff following burning (Johansen et al. 2001). With the used of prescribed burning, there is opportunity for specific areas to be left unburnt downslope of the burnt areas, to reduce runoff and contaminant transfer. However, there is also limited information worldwide on the use of vegetative buffers as a post-fire erosion control measure. Some research has been done on post-fire application of mulches, biosolids or logs (see for example Wohlgemuth 2003) but little quantitative work on buffer strips. Without such work, it is difficult to establish guidelines on the optimum practices for pasture burning near reservoirs or to introduce effective post-fire erosion control methods such as buffer strips.

Field simulated rainfall experiments were therefore used to investigate the effectiveness of buffer strips of un-grazed natural pasture grass in reducing the overland transport of sediments and associated pollutants in the rainfall-runoff following burning of pastures near Wivenhoe Dam. Wivenhoe is the major water supply reservoir for Brisbane City. Pasture buffer strips were pre-wet by simulated rainfall and then subject to runoff from plots upslope of the pasture strips which had been previously subject to burning. The major objective of the study was to compare the amounts of sediment, dissolved or total nutrients and carbon in the runoff that exited through pasture buffers of length 5, 2 and $0 \mathrm{~m}$ (i.e. no buffer), in the downslope direction of flow, thus evaluating the effect of buffer length on pollutant transport.. 
The runoff water quality was also compared between two types of pasture in the site area, namely: pastures that are seldom inundated by the dam water and pastures that are frequently inundated.

\section{Methods and materials}

\section{Site details}

The field rainfall simulations were carried out in the Wivenhoe Dam catchment, some $70 \mathrm{~km}$ north west of Brisbane. The broad catchment area of the dam is $5730 \mathrm{~km}^{2}$, of which $\sim 41 \%$ is used for pasture (Healthy Waterways, 2009).When at full capacity, the Dam can hold 1.16 million Mega litres. The catchment is subtropical and has a mean annual rainfall of $911 \mathrm{~mm}$. The site area was in Mojoo Bay (27 $20^{\prime} 28^{\prime \prime} \mathrm{S}$ and $\left.152^{\circ} 34^{\prime} 56^{\prime \prime} \mathrm{E}\right)$, which has slopes of 4$10 \%$ that are under native pasture. The geology at the site consists of flood plain alluviums and soil profiles show little sign of pedological development. Two pasture types were evaluated. The seldom inundated pastures (SIP) are located above the full capacity waterline of the reservoir and are currently leased as grazing land for cattle. The frequently inundated pastures (FIP) are below the maximum water mark and are grazed under license. SIP plots were on soils with higher sand and lower clay contents (sandy clay loams) than FIP (clay loams). Mean contents of total organic carbon, total nitrogen and total Kjedahl phosphorus (TOC, TN, TKP) in the topsoils $(0-10 \mathrm{~cm})$ prior to burning were $14.9,1.1$ and $0.4 \mathrm{mg} / \mathrm{g}$ for the SIP and 11.3, 0.5 and $0.1 \mathrm{mg} / \mathrm{g}$ for the FIP plots.

Plant type and percentage of cover were different for the two pasture types. The grasses on the SIP were sparse and close to maturity (thus dry and easy to burn). They consisted mostly of purple wire grass (Aristida ramosa var. speerosa) and weeping lovegrass (Eragrostris spp). Grass cover on the FIP was denser, greener and shorter, thus harder to burn. The most common grasses of the FIP were black spear grass (Heteropogon contortus), 
Chichory (Cichorium intybus) and Couch (Cynodon dactylon). Both pasture types were under the same grazing management prior to being fenced-off to exclude grazing. Rainfall simulation experiments, in the fenced area, were carried out one year after fencing, thus allowing one year of uninterrupted pasture regrowth before testing. Regular grazing of SIP prior to fencing of the experimental site, and the lower moisture in the soil profile (relative to FIP ), may have both contributed to reduced prevalence of the densely growing and more palatable grass species in favour of those less palatable and more sparsely growing (Tran and Gilroy 2006). Bare patches of soil could frequently be seen between basal stumps of pasture on SIP.

\section{Pasture burning}

Burning of the pastures was conducted the day prior to the start of rainfall simulation experiments. Due to the varying plant type and amount of ground cover, there was a difference in the intensity of the burning between the SIP and FIP plots. The fire was intense and fast moving across SIP plots while burning on the FIP plots was slow and needed plenty of encouragement to spread, resulting in less exposed area of soil surface on the burnt plots of the FIP.

\section{Provision of the buffer strips}

Grass buffer strips employed on land or on the banks of waterways, with the intention of protecting water quality, normally have a length of $10-50 \mathrm{~m}$. Providing such a length for rainfall simulation studies was difficult as the rain had to fall over the buffer strip as well as the experimental plot for the results to be realistic. The longest rainfall simulator which we could assemble was of length $12 \mathrm{~m}$, providing $10 \mathrm{~m}$ of uniform rain coverage. Because of this 
limitation, and based on our own experiences in grass strip investigation under simulated rainfall (Ghadiri et al. 2001; Rose et al. 2003; Hussein et al. 2008), it was decided to investigate the sediment trapping effectiveness of 2 and $5 \mathrm{~m}$ wide grass buffer strips (i.e. strips of unburnt pasture). Results obtained from burnt plots with buffer strips were compared with those from plots without such strips (i.e. buffer $=0 \mathrm{~m}$ ) or from unburnt plots. Figure 1 shows the rainfall simulator set-up on a burnt plot with no buffer. Rainfall simulation experiments were therefore carried out in two groups, one group of nine on the SIP and another nine on the FIP (Table 1) with three replications for each buffer length. Plots were 1.5 $\mathrm{m}$ width and 5, 7 or $10 \mathrm{~m}$ long (Table 1). Plot slopes averaged $4.8 \pm 0.6 \%$.

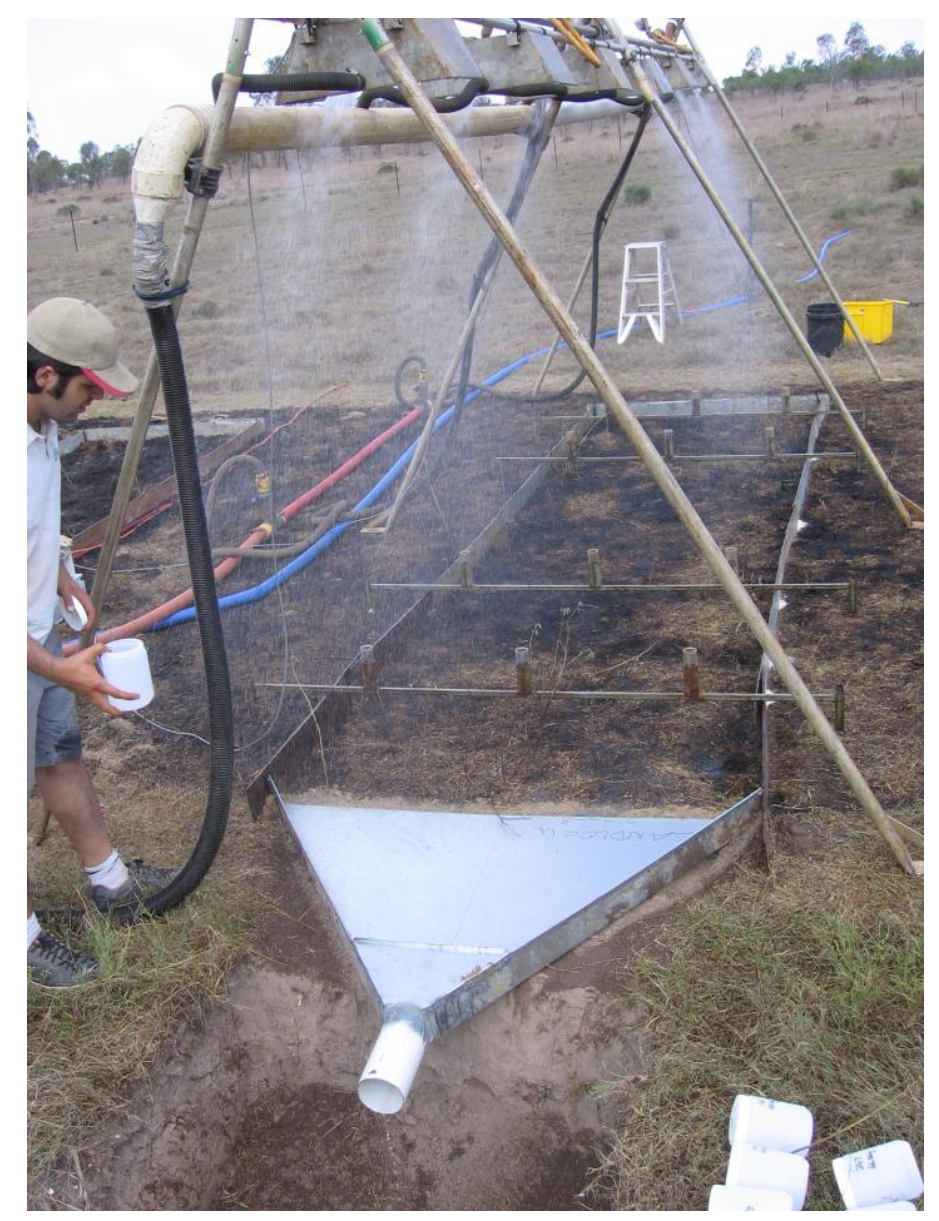

Fig. 1. Rainfall simulation equipment on a burnt SIP plot with no buffer. 
Table 1. Lengths of experimental plots under rainfall simulation

\begin{tabular}{lcccc}
\hline $\begin{array}{l}\text { Pasture } \\
\text { type }\end{array}$ & $\begin{array}{c}\text { Burnt plot length } \\
(\mathrm{m})\end{array}$ & $\begin{array}{c}\text { Buffer plot length } \\
(\mathrm{m})\end{array}$ & $\begin{array}{c}\text { Total plot length } \\
(\mathrm{m})\end{array}$ & \begin{tabular}{c} 
Replicates \\
\hline SIP
\end{tabular} \\
\cline { 2 - 5 } & 5 & 0 & 5 & 3 \\
\cline { 2 - 5 } & 5 & 2 & 7 & 3 \\
\hline FIP & 5 & 5 & 5 & 3 \\
& 5 & 0 & 7 & 3 \\
\hline & 5 & 2 & 10 & 3 \\
\hline
\end{tabular}

\section{Rainfall simulation experiments}

As shown in Table 1, a total of 18 rainfall simulations were carried out on the plots. A 12 meter-long oscillating, spray-type simulator was used, consisting of four $3 \mathrm{~m}$-long modules, equipped with rain and runoff rate measuring devices (as described by Loch et al. 2001). Rainfall could thus be applied over part or all of the plot area. This simulator uses Veejet 80100 nozzles which provide a high uniformity of rainfall coverage (with $<5 \%$ variation across the length and width of the plots. Water for the simulator was sourced from a nearby spring. The concentration of soluble chemicals in this water was low (FRP $0.01 \mathrm{mg} / \mathrm{L} ; \mathrm{NOx}+$ $\mathrm{NH}_{4}{ }^{+} 0.6 \mathrm{mg} / \mathrm{L}$ and DOC $\left.8.7 \mathrm{mg} / \mathrm{L}\right)$. A rainfall rate of $100 \mathrm{~mm} / \mathrm{h}( \pm 6 \%)$ was used and the duration of experiments were for $\sim 30$ minutes for no-buffer plots (Fig.1) and $\sim 60$ minutes for plots with buffers, based on the speed of runoff initiation following the start of the simulated rainfall. This rainfall rate simulates a one in thirty year rainfall event for this area.

Rainfall simulation experiments on all plots with a 2 and $5 \mathrm{~m}$ buffer width were carried out for 60 minutes as follows: During the first 30 minutes, only the simulator unit spaying 
water on the buffer strip was turned on. This served the two purposes of wetting up the buffer zone and also producing base-line information for sediment loss from unburnt plots.

Sampling was done at 5 minute intervals. In the second 30 minutes the simulator modules

producing rainfall on the upslope burnt plot were also turned on and runoff sampling from the downslope end of the buffer strips continued at the same 5 minutes interval for another 30 minutes.

Two half litre samples were collected every 5 to 8 minutes during the run, one for the determination of sediment concentration and another for chemical analysis. Sampling time was recorded for all the samples and used for calculating flow rate and its variation during runs. Samples were immediately stored at $<4^{\circ} \mathrm{C}$ temperature and were then transported to the laboratory at the Nathan campus of Griffith University for subsequent physical and chemical analyses. Composite soil samples were also taken before and after each simulation from the plots at $0-10 \mathrm{~cm}$ for baseline determination of nutrient contents. While soil erosion may be expected to have more effect on the top few $\mathrm{cm}$ of soil, the $10 \mathrm{~cm}$ depth ensured greater sampling reproducibility given the large variations in micro-topography/organic debris in the plots. Soils were stored, transported to the laboratory and analysed in the same way as the sediment samples.

\section{Laboratory analysis}

The volume of the collected sediment concentration samples was first determined and then the weight of sediment (total suspended solids, TSS) was measured by oven drying to constant weight at $105^{\circ} \mathrm{C}$. Sediment concentration (mg/L) was then calculated using sample volume and sediment dry weight. Runoff rates were determined from volumes of runoff 
collected within the measured times. The product of sediment concentration and runoff rate gave the sediment loss rate (hereafter denoted SLR), which was measured in $\mathrm{kg} / \mathrm{ha} . \mathrm{h}$.

The second group of refrigerated runoff samples (chemical samples) once in the lab were immediately filtered. The filtrates were analysed for soluble nitrogen $\left(\mathrm{NO}_{3}{ }^{-}, \mathrm{NO}_{2}{ }^{-}\right.$and $\left.\mathrm{NH}_{4}{ }^{+}\right)$ filterable reactive phosphorus (FRP) and dissolved organic carbon (DOC) using flow injection analysis (FIA). The $\mathrm{NO}_{3}{ }^{-}$and $\mathrm{NO}_{2}{ }^{-}$collectively are called $\mathrm{NO}_{\mathrm{X}}$. The sediments collected on the filter paper were analysed for total Kjeldahl nitrogen (TKN) and phosphorus (TKP) by digestion and FIA analysis (Diamond 1996). TKN is the sum of organic $\mathrm{N}$ and ammonium N. Total organic carbon (TOC) and total nitrogen (TN) in the sediments were analysed by an Elemental Analyser using Dumas combustion. Chemical analyses similar to those carried out on the sediments were also carried out on the soil samples collected before and after each experiment.

\section{Statistical analyses}

Data were analysed by 2 factor analysis of variance using SAS (version 9.2; SAS Institute Inc., Cary, N.C). Factors were pasture type (SIP, FIP) and buffer length (0, 2 or $5 \mathrm{~m})$. Variables were the SLR, the soluble and the total nutrients/carbon concentrations in the runoff respectively. Relationships between variables were analysed by regression analysis.

\section{Results}

\section{Sediment transport in runoff}

During the rainfall simulations, runoff from the burnt plots was observed to carry more sediment and floating debris than those from unburnt plots. Subsequent analysis of the sediment samples for their organic/inorganic matter contents showed that up to $38 \%$ of the mass of sediment collected in the runoff samples consisted of organic matter. The proportion 
of organic matter in the sediment samples varied between the two pastures and with the buffer length treatments (see section: TKP, TN, TKN and TOC in the runoff.) Both organic and inorganic solids can contribute to dam water pollution, therefore they have been collectively called "sediment" in this section.

In the burnt plots, the scorched plant residue on the soil surface affected the flow pattern over the plot and its ability to transport sediments. Generally, a large number of small ponds were created by floating material trapped behind grass stumps or surface irregularities. This condition prevented the development of rills, which are usually a major contributor to soil erosion by sediment entrainment on agricultural or some pasture lands or on burnt areas (Wohlgemuth 2003). The ponded water in these small ponds also protected the soil from raindrop impact, thus reducing soil particle detachment by rain.

When buffer strips were present at the exit from test runoff plots, most of the sediment or floating material was carried toward the low slope end of the plots and this accumulated against the first row of the unburnt plants of the buffer strip. The accumulation at the start of the buffer strips added to the efficiency of the buffer in slowing down the surface runoff, thus causing further deposition of suspended sediment in this ponded "backwater" region (Ghadiri et al. 2001; Rose et al. 2002; Hussein et al. 2007). Although most sediment deposition took place in the backwater region, there was also some deposition observed inside the grass strip area, especially on the SIP plots.

Measured sediment concentrations in the runoff were not high, generally being $<1 \mathrm{~g} / \mathrm{L}$, and, as is commonly observed, the concentration decreased with time in an approximately negative exponential form, with this decline becoming quite limited after $\sim 30$ minutes of rainfall. Whether soil erosion is dominated by rainfall or overland flow, the physical reasons for such decline to steady state are well understood (e. g. Sander et al. 1996; Rose et al. 2007). In contrast, and again for well understood physical reasons (Marshall et al. 1996), infiltration 
rate under the constant-rate simulated rainfall was observed to decline with time, resulting in an increase in runoff coefficient with time, which became approximately constant after some 30 minutes under rainfall. Because of the opposed types of time behaviour of sediment concentration and runoff rate, the product of the two, sediment loss rate (SLR in $\mathrm{kg} / \mathrm{ha} . \mathrm{h}$ ), was therefore approximately constant with time for most experiments. This is illustrated in Fig. 2 for the FIP 0 and $5 \mathrm{~m}$ buffer plots and for the SIP $5 \mathrm{~m}$ buffer plot. However, occasionally, there was some variation as shown by the SIP $0 \mathrm{~m}$ plot in Fig.2, possibly due to the large amount of sediment loss. Since the main focus of this study is the effect of width of grass buffer strips and pasture type on sediment and chemical loss, comparisons will be made in terms of the mean SLR (over the time range) for each plot.

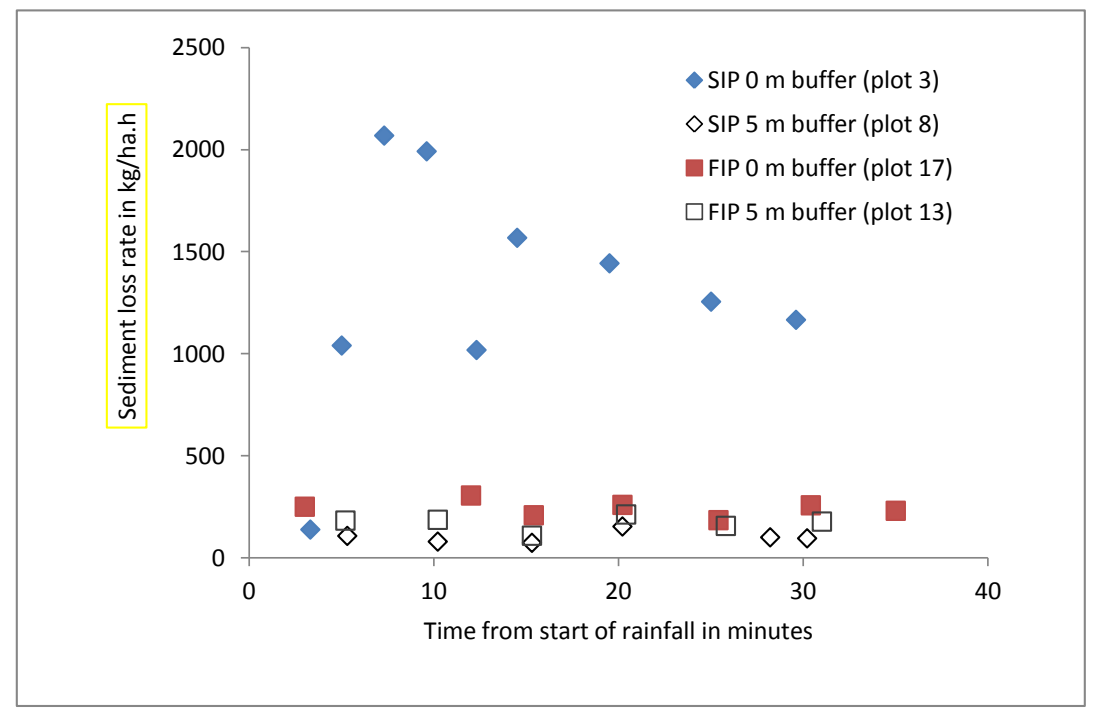

Fig 2. Changes in sediment loss rate (SLR) with time for SIP and FIP pasture simulations for no buffer ( $0 \mathrm{~m}$ buffer) and $5 \mathrm{~m}$ buffer plots.

Mean SLR from SIP burnt plots ranged from 62 to $2281 \mathrm{~kg} / \mathrm{ha} . \mathrm{h}$ and for FIP burnt plots from 45 to $432 \mathrm{~kg} / \mathrm{ha} . \mathrm{h}$. The highest mean SLR (2281 kg/ha.h) occurred from SIP (plot 4) 
with no buffer (buffer $=0 \mathrm{~m}$ ). This was probably due to the lack of soil cover in this plot following burning. Mean SLR values from unburnt plots were $104 \pm 44$ and $161 \pm 88 \mathrm{~kg} / \mathrm{ha} . \mathrm{h}$ from the SIP and FIP plots respectively. Burning increased SLR relative to the mean SLR on unburnt plots by factors of up to 20 times on SIP plots and up to 8 times on FIP plots. Increases in sediment yield following burning have likewise been noted by many researchers (see for example Lane et al. 2006; Ferreira et al. 2008). Johansen et al. (2001) measured sediment increases of up to 6 times in burned pastures compared to unburned pastures under $60 \mathrm{~mm} / \mathrm{h}$ rainfall simulation on $3 \times 10.7 \mathrm{~m}$ plots in New Mexico, USA. Increasing buffer length reduced SLR (Fig. 3), particularly for SIP plots whose cover was much more open than FIP plots. Analysis of variance for SLR indicated that there were significant effects due to the different buffer lengths $(P=0.015)$ and pasture type $(P=0.03)$ and the interaction of burning method by pasture type was also significant $(P=0.039)$.

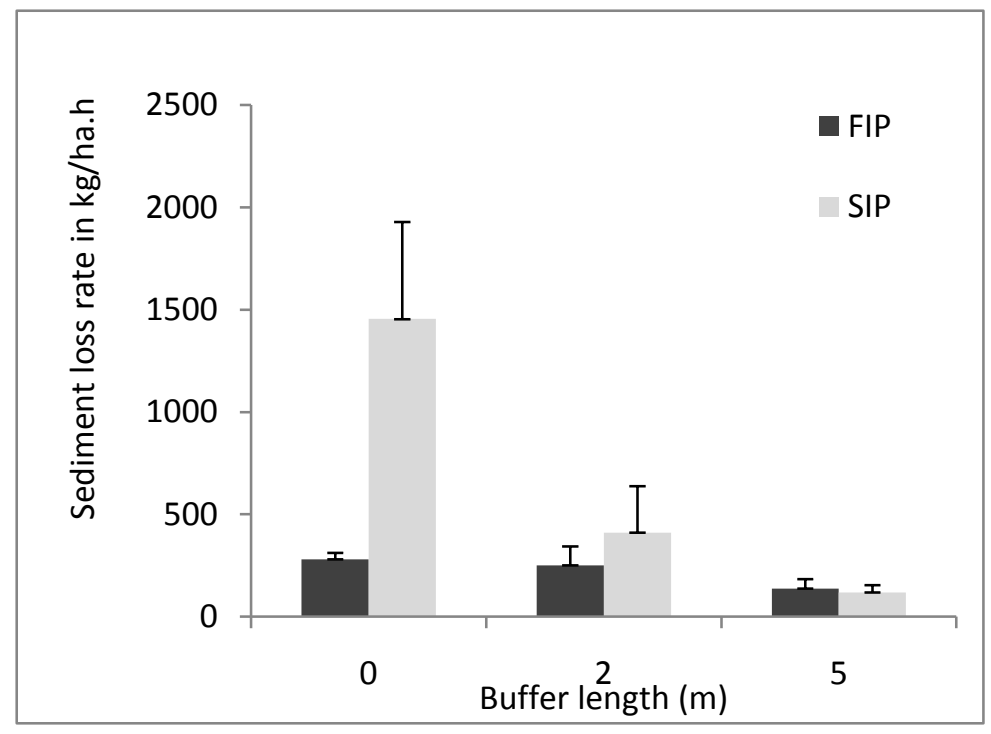

Fig. 3. Time averaged sediment loss rate (SLR) as affected by buffer length for SIP and FIP. Bars indicate the standard error of the mean.

\section{Soluble chemicals in the runoff}

The concentrations of the soluble chemicals, FRP, $\mathrm{NO}_{\mathrm{X}}$ and $\mathrm{NH}_{4}{ }^{+}$in the runoff were generally constant during the simulation period, as illustrated in Fig. 4 for one of the SIP plots with no 
buffer. In contrast, DOC concentration usually decreased with time and then reached equilibrium (approximately equal to the rainfall water concentration- see section on Rainfall simulation experiments) at around 30 minutes into the simulation experiments (Fig. 4). The change with time may be due to differing solubilities of the complex carbon components remaining after burning (DeBano et al., 1998).

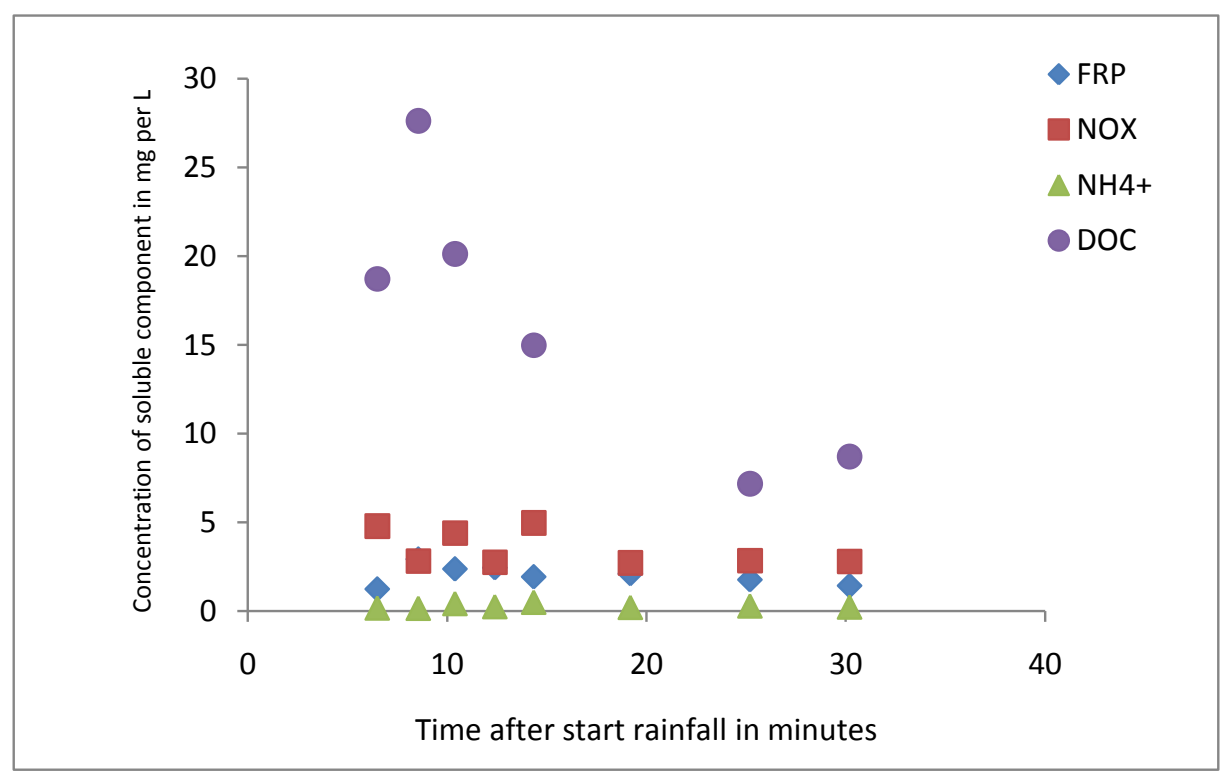

Fig. 4. Changes in concentration of FRP, NOX, NH4+ and DOC with time after start of rainfall for a SIP plot with no buffer (0 $\mathrm{m}$ buffer).

To analyse the effect of buffer length on the water quality of the runoff, the mean concentrations of the soluble chemicals during the 30 minutes of rainfall have been used. Mean FRP concentrations in the runoff from burnt plots varied between 0.25 and $2.04 \mathrm{mg} / \mathrm{L}$ in contrast to mean concentrations of $0.31 \pm 0.07$ and $0.51 \pm 0.18 \mathrm{mg} / \mathrm{L}$ for SIP and FIP Plots respectively. Concentrations from burnt plots were thus generally higher than from unburnt SIP and FIP plots (0.31 and $0.51 \mathrm{mg} / \mathrm{L}$ respectively) although 3 plots had slightly lower FRP concentrations, most likely due to plot variability. Miller et al.(2006) found that burning of forest sites likewise significantly increased levels of phosphate $\mathrm{P}$ in runoff with runoff concentrations as high as $5 \mathrm{mg} / \mathrm{L}$. The increased FRP concentration in the runoff is due to the 
large amounts of highly available $\mathrm{P}$ that can be found in ash immediately after fires (DeBano et al. 1998). Buffer length had a significant effect on FRP levels $(P=0.0001)$ with most reduction within the $2 \mathrm{~m}$ buffer (Fig. 5a). This is presumably due to adsorption of FRP to soil particles and exposed plant roots with which this chemical came in contact during the passage of runoff through the buffer strips. Further extension of the buffer length to $5 \mathrm{~m}$ gave varied results with the mean FRP concentration decreasing for the SIP and increasing for the FIP, possibly due to plot variability. There were no significant effects due to pasture type and no significant interactions.

Fig 5 a

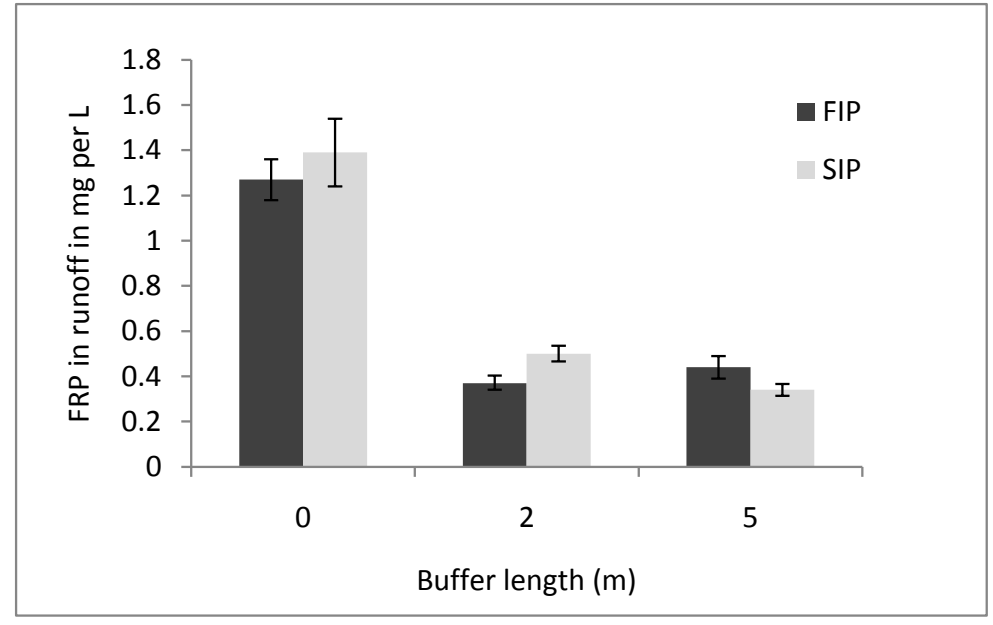

Fig $5 b$

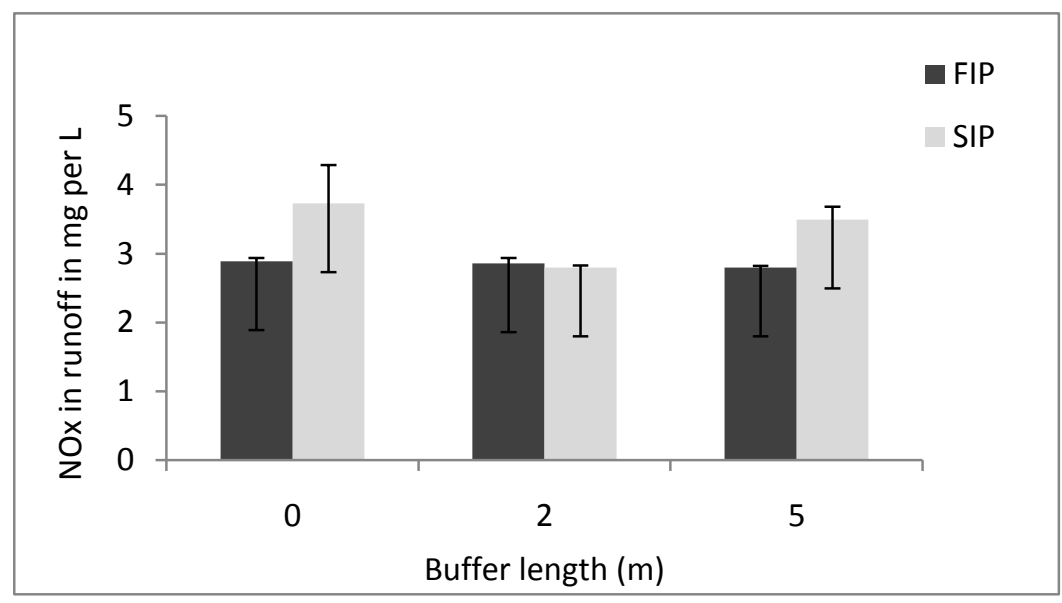


Fig 5c

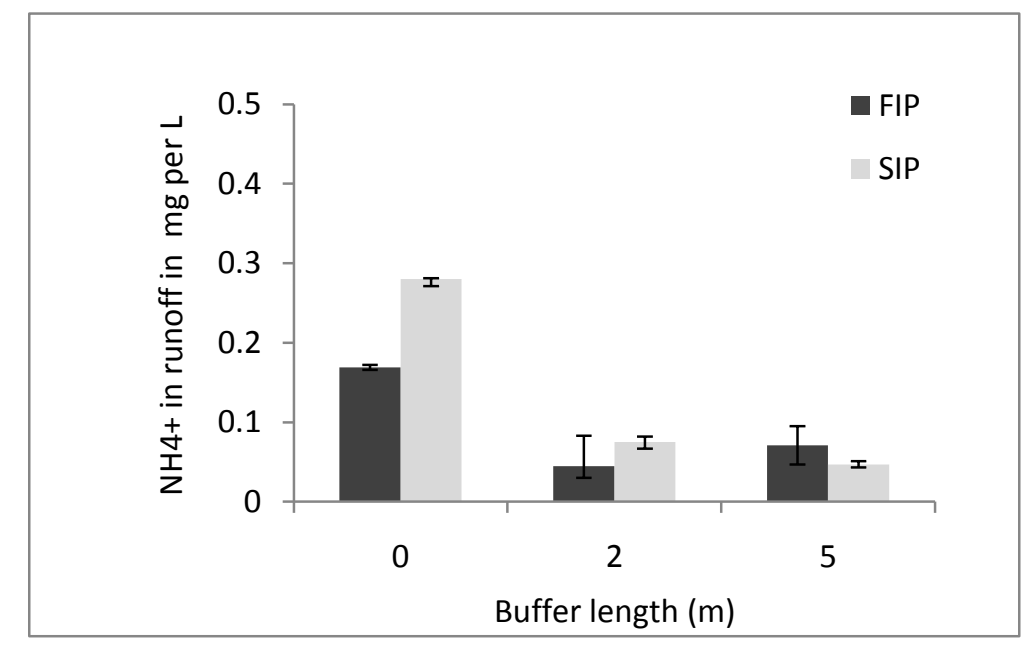

Fig $5 d$

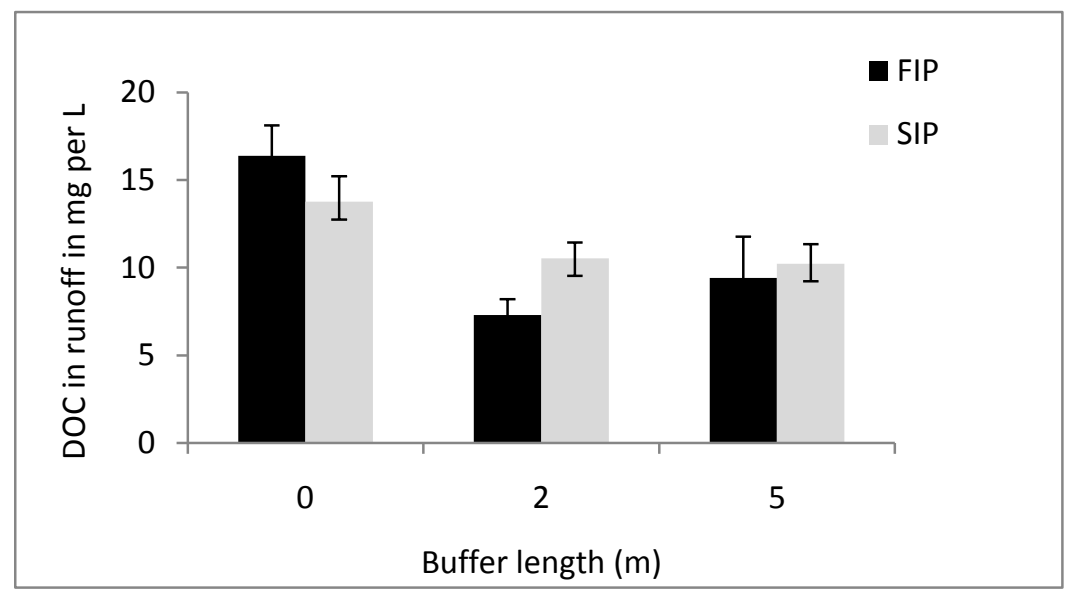

Fig. 5. Concentration of FRP (a); NOx (b) NH4+ (c) and DOC (d) in the runoff as affected by buffer length for SIP and FIP plots. Bars indicate the standard error of the mean.

Soluble nitrogen in the runoff was primarily composed of $\mathrm{NO}_{\mathrm{X}}$ (range 2.7 to $4.8 \mathrm{mg} / \mathrm{L}$ ) as $\mathrm{NH}_{4}{ }^{+}$concentrations were low $(<0.29 \mathrm{mg} / \mathrm{L})$. Examination of soluble $\mathrm{NO}_{\mathrm{X}}$ components showed that nitrite $\left(\mathrm{NO}_{2}^{-}\right)$levels were negligible (generally $<0.01 \mathrm{mg} / \mathrm{L}$ ) and the $\mathrm{NO}_{\mathrm{X}}$ therefore essentially comprised $\mathrm{NO}_{3}{ }^{-}$. The $\mathrm{NO}_{\mathrm{X}}$ values from the burnt plots were somewhat similar to those of unburnt plots $(3.72 \pm 0.58$ and $2.82 \pm 0.03 \mathrm{mg} / \mathrm{L}$ for SIP and FIP respectively). It therefore appears that burning had little effect on $\mathrm{NO}_{\mathrm{X}}$ levels. DeBano et al. 
(1998) reported that large amounts of ammonia-N are formed during and after burning of vegetation but that the burning does not produce nitrates. Nitrates are instead formed after burning, by nitrification of the ammonia by the soil microbial population. Any $\mathrm{NO}_{\mathrm{X}}$ in the runoff from our study was therefore most likely from pre-existing soil/pasture nitrates.

Simulations were carried out within a day of burning which probably precluded the time for full nitrification to occur from ammonia. Buffers had no significant effect on $\mathrm{NO}_{\mathrm{X}}(P=0.17)$, and there was no clear trend in concentration as buffer length increased (Fig. 5b). Pasture type was significant $(P=0.033)$ but the interaction between buffer length and pasture was not.

Soluble $\mathrm{NH}_{4}{ }^{+}$values ranged from 0.01 to $0.29 \mathrm{mg} / \mathrm{L}$, compared to means of $0.05 \pm 0.01$ and $0.09 \pm 0.04 \mathrm{mg} / \mathrm{L}$ for unburnt SIP and FIP plots respectively. In contrast to $\mathrm{NO}_{\mathrm{X}}$, soluble $\mathrm{NH}_{4}{ }^{+}$concentrations in the runoff usually increased with burning. This is most likely due to increase concentrations of ammonia- $\mathrm{N}$ in the ash, immediately post fire, as reported by DeBano et al. (1998) and Wan et al. (2001). The $\mathrm{NH}_{4}{ }^{+}$concentration generally decreased with increasing buffer length (Fig. 5c). Buffer length and pasture type were significant for $\mathrm{NH}_{4}{ }^{+}(P=<0.0001$ and $P=0.015)$ and their interaction was also significant $(P=0.006)$.

DOC in runoff from burnt plots varied from 5.1 to $19.5 \mathrm{mg} / \mathrm{L}$, with mean DOCs of $9.6 \pm 4.8$ and $10.4 \pm 4.3 \mathrm{mg} / \mathrm{L}$ (unburnt SIP and FIP plots). Buffer length was significant $(P=0.0096)$ but pasture type and interactions were not significant. DOC changes with buffer length were somewhat varied (Fig. 5d), decreasing for the $2 \mathrm{~m}$ buffers but increasing between the 2 and 5 $\mathrm{m}$ buffer for the FIP plots. This may be due to gradual addition of DOC from pasture/soil in the FIP buffer zone

TKP, TN, TKN and TOC in the runoff

The effect of different width buffer strips on the runoff transport of total nutrients and carbon (TKP, TKN, TN, and TOC) was examined. The predominant component in the runoff was TOC, with concentrations ranging from 25 to $218 \mathrm{mg} / \mathrm{g}$. Mean TOC in runoff from unburnt 
SIP and FIP plots were $87 \pm 30$ and $58 \pm 42 \mathrm{mg} / \mathrm{g}$ respectively, thus showing a large variation between replicated plots as was found for the DOC above. This was also the case for the burnt plots; nevertheless, there were significant buffer effects $(P=0.022)$ and pasture type effects $(P=0.019)$ for TOC, but the interaction was not significant. Fig. 6 indicates that TOC decreases significantly for the $2 \mathrm{~m}$ buffer followed by some increases for the $5 \mathrm{~m}$ buffer, possibly through secondary removal and transport of floating organic matter within the buffer zone.

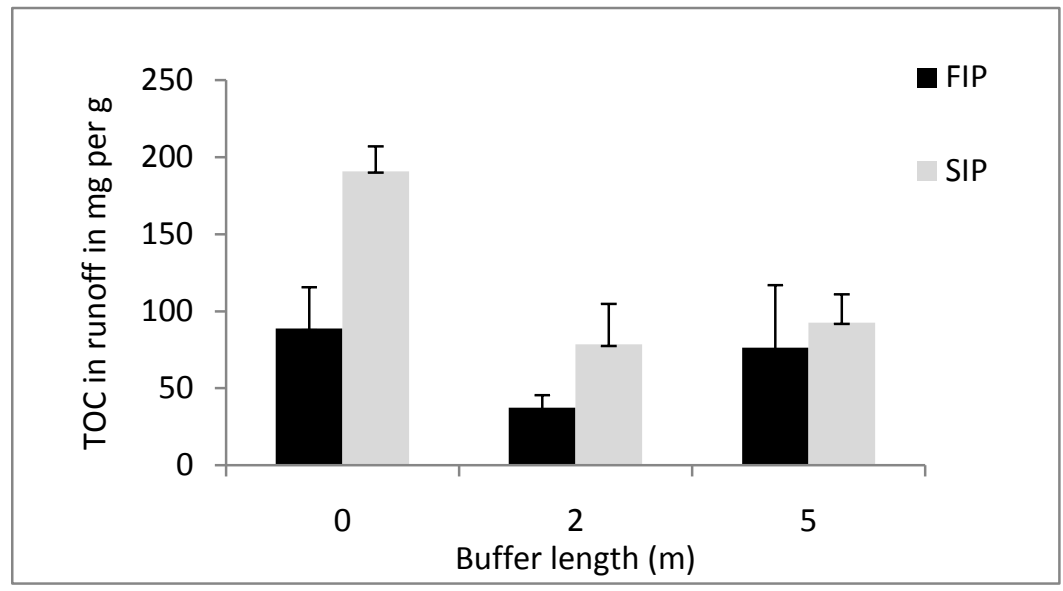

Fig. 6. Concentration of TOC in the runoff as affected by buffer length for SIP and FIP plots. Bars indicate the standard error of the mean

Mean TKP in the burnt plot runoff varied between 0.09 to $1.07 \mathrm{mg} / \mathrm{g}$ in contrast to the unburnt plots $(0.35 \pm 0.11$ and $0.40 \pm 0.39 \mathrm{mg} / \mathrm{g}$ for SIP and FIP respectively). TKP decreased with increasing buffer length but buffer length, pasture type and the interaction were not significant. TKN concentrations in runoff ranged from 0.17 to $3.79 \mathrm{mg} / \mathrm{g}$ (SIP unburnt $1.3 \pm$ 0.83; FIP unburnt $1.32 \pm 1.57$ ) and buffer length, pasture type and their interaction were not significant. TN concentrations in runoff from burnt plots varied from 1.9 to $11.31 \mathrm{mg} / \mathrm{g}$ (SIP unburnt $5.21 \pm 1.52$; FIP unburnt $3.73 \pm 2.55 \mathrm{mg} / \mathrm{g}$ ). Buffer length, pasture type and their interaction were again not significant. 
The total amount of these chemicals in the runoff can amount to large values when there is high sediment loss. Thomas et al. (1999) found there was an increase in loss of total phosphorus by three to four orders of magnitude following forest burning. In our study, the highest SLR occurred from the hot burn SIP (plot 4) with no buffer (SLR =2281 kg/ha' hr). This would equate to losses of 2.1; 7.7; 18.1 and $369 \mathrm{~kg} / \mathrm{ha}$ hr of TKP, TKN, TN and TOC respectively under this intense rainfall, at the respective chemical concentrations for this plot. While some of this pollutant load would be reduced by further deposition downslope from the burnt plots, these high loads in the runoff from burnt pasture could still have the potential to contribute pollutant loads into the reservoir.

\section{Effect of buffer length on reduction of SLR and soluble runoff loads}

To quantify the effect of buffer length in reducing some runoff pollutants that are important for water quality, data were assessed in more detail. Figures $7 \mathrm{a}$ and $\mathrm{b}$ illustrate the reduction in runoff loads with respect to buffer length for the SLR and some soluble parameters. Mean data \pm standard errors from the six plots at each respective buffer length are used for simplicity in these Figs. The parameters show a decrease in concentration between 0 to $2 \mathrm{~m}$ but only the SLR shows a further marked decrease from 2 to $5 \mathrm{~m}$.

Exponential curves were fitted to all the data relating buffer width to concentration of the different parameters (see legends for Figs. 7a, b). The curves for SLR and the soluble components, FRP, $\mathrm{NH}_{4}{ }^{+}$and DOC, had moderate to low $R^{2}$ values $\left(R^{2}=0.52 ; 0.59 ; 0.66\right.$ and 0.24 respectively) and significant $\mathrm{F}$ values $(P=0.007 ; 0.0002 ;<0.0001$ and 0.04 respectively $)$, while the curves for $\mathrm{NO}_{\mathrm{X}}$ had non-significant $\mathrm{F}$ and low $R^{2}$ values. Those curves with significant $\mathrm{F}$ values could be used to predict runoff concentrations under the same rainfall conditions for buffers slightly longer than $5 \mathrm{~m}$ (see discussion section). However, changes in 
slope, soil type or pasture vegetation could affect the runoff predictions so the equations should be used with caution.

Fig $7 \mathrm{a}$

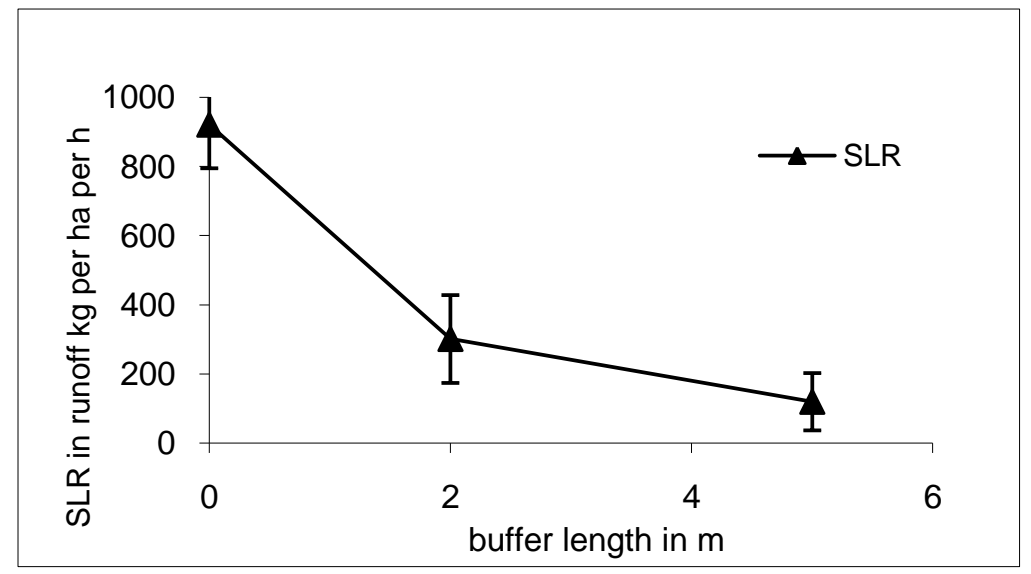

Fig $7 b$

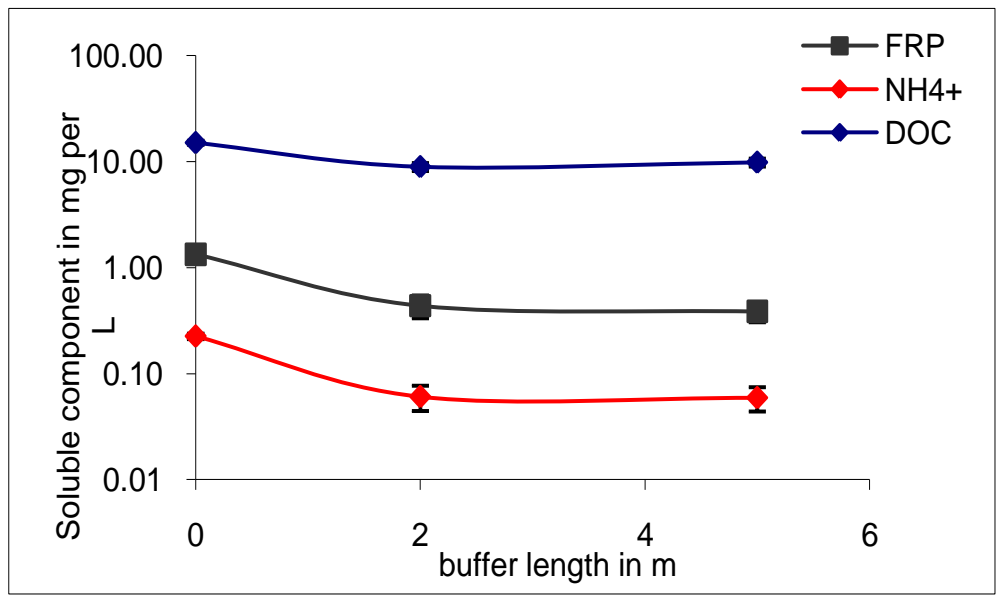

Fig. 7a. Effect of buffer length on Sediment loss rate (SLR) using mean data \pm standard error. Exponential regression for all data: $y=626.4$ e $-0.385 x(y=S L R$ and $x=$ buffer length in $\mathrm{m})$

Fig. 7b. Effect of buffer length on FRP, NH4+ and DOC using mean data \pm standard errors Exponential regression for all FRP data: $y=1.01-0.233 x \quad(y=F R P$ and $x=$ buffer length in m) Exponential regression for all NH4+ data: $y=0.18-0.254 x(y=N H 4+$ and $x=$ buffer length in $\mathrm{m})$. Exponential regression for all DOC data: $\mathrm{y}=12.90-0.082 \mathrm{x}(\mathrm{y}=$ DOC and $\mathrm{x}=$ buffer length in $\mathrm{m}$ ) 


\section{Effect of grass buffer strips on the enrichment of sorbed chemical in runoff}

Preferential transport of finer particles in runoff causes the particles and their sorbed nutrients and chemicals to be enriched in the eroded sediment compared to the original soil from which they originate (Ghadiri and Rose 1991a,b; Johansen et al. 2001). However such concentrations are dependent on the availability of these chemicals in the original soil. Buffer strips may be quite effective in removing the bulk of the sediment from runoff, but the fine sediment fraction which passes through the buffer is often richer in chemicals than the eroding soil, thus rendering the strip less effective in preventing surface water pollution than would appear. Thus, to further evaluate the effectiveness of buffer strips in reducing such pollutants, the effects of the presence and width of grass buffer strips on the enrichment of the total nutrient and carbon were assessed using enrichment ratios (ER). ER values are calculated by dividing the concentration of the parameter in the eroded sediment by the concentration of the same parameter in the original soil (see Section on Site Details). The ER values (Table 2) ranged from 3.1 to 10.7 from burnt plots without buffers.

Table 2. Effect of buffer strip width on the enrichment ratio (ER) of total nutrients and organic carbon in the runoff sediment

\begin{tabular}{lcccc}
\hline $\begin{array}{l}\text { Pasture } \\
\text { condition }\end{array}$ & $\begin{array}{l}\text { Buffer } \\
\text { length }(\mathbf{m})\end{array}$ & ER(TKP) & ER(TN) & ER(TOC) \\
\hline Unburnt & - & 1.5 & 5.6 & 5.6 \\
\hline Burnt & 0 & 3.1 & 9.2 & 10.7 \\
\hline Burnt & 2 & 2.0 & 4.4 & 4.4 \\
\hline Burnt & 5 & 1.7 & 4.2 & 4.3 \\
\hline
\end{tabular}

The provision of a $2 \mathrm{~m}$ grass buffer strip cuts the ERs by $\sim 30-50 \%$, while increasing the width of buffer strip to $5 \mathrm{~m}$ only reduces ER values by a small additional amount. There were significant differences for ERs $($ T-test $P<0.05)$ between the burnt and unburnt plots for TKP and TN, and significant differences between the ER from $0 \mathrm{~m}$ buffers and $2 \mathrm{~m}$ buffers for TKP, TOC and TN indicating that the $2 \mathrm{~m}$ buffer could help to reduce enrichment. Johansen 
et al. (2001) noted ERs of 2.3 and 1.2 for sorbed-Caesium transport from burnt pastures in the USA but did not find significant differences between burnt and unburnt plots.

To estimate the approximate width of grass buffer capable of reducing the total nutrient and carbon to the level similar to those of unburnt soils, the ER values were plotted against the buffer widths and fitted with exponential curves. The regressions for TKP, and TN were significant $(P<0.05)$ and so equations for these curves were then used to estimate the width of buffer needed to lower the ER values to that of the unburnt pastures. The calculated buffer strip widths were: $\mathrm{TKP}=5.6 \mathrm{~m}$ and $\mathrm{TN}=2.3 \mathrm{~m}$. Therefore, under these experimental conditions, the minimum grass strip required to lower all the ER values to those from unburnt pastures is $6 \mathrm{~m}$. Such estimates needs to be treated cautiously as they assume the same slope throughout and intact buffer strips, free of the effect of grazing, cattle tracks etc.

\section{Discussion}

The burning of the pastures in this study lead to enhanced sediment, nutrient and carbon losses compared to unburnt pastures, when high intensity rainfall was applied shortly after burning. The only parameters that remained relatively unaffected by burning were the components of $\mathrm{NO}_{\mathrm{X}}$. As outlined previously, burning of vegetation produces ammonia-N (DeBano et al. 1998) rather than nitrates. The nitrates may be formed later by nitrification of the ammonia but nitrification may take from several days to several weeks depending on postfire conditions of moisture, temperature and ammonium concentration (see for example Malhi and McGill 1982; Carreira et al. 1994; Stange and Neue 2009) with temperatures of $\sim 30^{\circ} \mathrm{C}$ and moisture contents near field capacity generally being considered optimum for tropical soils. It is unlikely that nitrification occurred within one day of burning under the dry post- 
fire condition of this study. The $\mathrm{NO}_{\mathrm{X}}$ in the runoff from our study was therefore most likely from pre-existing soil/pasture nitrates.

The use of bounded plots and rainfall simulation to measure post-fire erosion losses allows control over a number of variables affecting these losses and provides a detailed spatial analysis of the runoff processes. However, Ferreira et al. (2008) note that these types of experiments have some disadvantages such as being dependent on vegetation type, hillslope position or because they are based on closed systems within the plot boundaries. These authors suggest that nested approaches may offer more insight into the erosion processes. For this study, the location of plots on two pasture types may help to address one of the important limitations identified by Ferreira et al. (2008). Other research has found that plot size affects soil loss (Hudson 1993; Cerda et al., 2008) with small plots often having larger and more variable soil loss than bigger plots as they exclude deposition points downslope. The effect of the buffer in modifying the soil loss and runoff will therefore depend on the size of the upslope burnt area as well as other factors such as convergence of runoff. The plot size in this study was however constrained by the size of the rainfall simulator. Future research may employ other techniques such as use of larger plot sizes or monitored catchment measurements to enhance our understanding of the processes involved at larger scale but in the meantime this research provides a treatment comparison of two pasture types and buffer strip length on erosion losses from five metre upslope plots.

A number of researchers have noted that the intensity of burning produced differences in soil properties, vegetation cover, water repellency, erodibility and runoff (Robichaud and Waldrop 1994; Benavides-Solorio et al. 2004; Coelho et al. 2004). DeBano et al. (1998) noted that the effects of burning are related to temperatures reached, length of burning and initial soil conditions amongst other things. The intensity of burning was observed to be higher for the SIP than FIP due to the dryer vegetation but was not quantified in these experiments. This 
higher intensity could have lead to greater ashing of vegetation and the rapid dissolution of this ash in the runoff water could help to explain the higher concentrations of many soluble and total nutrients from the SIP plots.

Burning resulted in large increases in sediment losses in the runoff. The buffers were clearly effective in removing sediment from the runoff in both SIP and FIP plots (Fig. 3) with the most dramatic reduction occurring with a $2 \mathrm{~m}$ buffer for the SIP plots. Most of the coarse sediment or floating material carried from the burnt plots accumulated against the first row of the buffer strips or deposited in the backwater region. This implies that the buffer strips behaved more like "barrier strips" than "filter strips" for all but very fine particles, as suggested by Ghadiri et al. (2001) and Rose et al. (2002).

Concentrations of chemicals in the runoff exceeded the Australia and New Zealand Environmental Conservation Council (ANZECC) trigger values for South East Australian lakes/reservoirs, even from the unburnt plots. According to ANZECC guidelines (2000), trigger values are $0.01 \mathrm{mg} \mathrm{N} / \mathrm{L}$ for $\mathrm{NO}_{\mathrm{X}} ; 0.01 \mathrm{mg} \mathrm{N} / \mathrm{L}$ for $\mathrm{NH}_{4}^{+} ; 0.005 \mathrm{mg} \mathrm{P} / \mathrm{L}$ for FRP; $0.35 \mathrm{mg} \mathrm{N} / \mathrm{L}$ for TN and $0.01 \mathrm{mg}$ P/L for TP. Runoff from burnt plots without grass buffers often exceeded these trigger values by >100 times. Ferreira et al. (2008) note that typically plot runoff concentrations exceed catchment concentrations by between 2 and 9 times.

The levels of the pollutants in the runoff clearly have the potential for downslope pollution so that some management action is required. Buffer strips up to $5 \mathrm{~m}$ wide were not effective in reducing $\mathrm{NO}_{\mathrm{X}}$ but appear to have some effect in removing $\mathrm{FRP}$ and $\mathrm{NH}_{4}{ }^{+}$from runoff. SLR also showed a significant exponential decline pattern with the strip width (Fig.7a). A first order rate equation was developed to provide an approximate prediction of the effectiveness of buffer strips wider than those investigated in removing sediment from runoff. However such extrapolations from 2 and $5 \mathrm{~m}$ buffer strips to longer strips must be treated cautiously as the results are based on runoff generated from small plots, which may 
differ substantially in behaviour to runoff generated on large catchments of several hectares and under natural rain (Ferreira et al.2008).

The concentrations of FRP and $\mathrm{NH}_{4}{ }^{+}$also follow an exponential decline with length of buffer strip, which can be used cautiously to estimate the effectiveness of wider grass strips in removing these chemicals from runoff (Fig 7b). This exercise suggests that grass buffers of $\sim 23$ and 11 m length may be capable of lowering the concentrations of FRP and $\mathrm{NH}_{4}{ }^{+}$ respectively in the runoff from burnt pasture to a level which may not cause ecosystem stress in the dam reservoir.

Organic materials which form DOC in the runoff are responsible for degraded taste, odour and colour of water and the formation of carcinogenic disinfection by-products during water treatment. However, there are no current trigger values for DOC. Levels of DOC in the runoff were slightly enhanced by burning and buffer strips generally reduced DOC levels.

Burning increased the concentrations of TKP, TKN, TN and TOC in the runoff sediment. The predominant component amongst these was TOC. The grass buffers reduced concentrations of all these parameters with most reduction occurring within the first $2 \mathrm{~m}$ of buffer, particularly for the TOC and TN. Further reductions within the $5 \mathrm{~m}$ buffer were only achieved with the TKN and TKP. This relative independence of buffer length is because a large proportion of eroded sediment, consisting largely of floating organic residue, accumulated against the first row of grass in the buffer strip. As shown in detailed studies by Ghadiri et al. (2001) and Rose et al. (2002, 2003), this is also due to the reduction in flow velocity (favouring net deposition) in a backwater region caused by the buffer strip.

When comparing the absolute losses of nutrients and carbon, the losses of total components in the sediment were generally larger than the soluble forms. For example, using data from the plot with the highest sediment loss (SIP plot 4, no buffer), average sediment 
concentration was $5.12 \mathrm{~g} / \mathrm{L}$. For a hypothetical runoff of $200 \mathrm{~L}(\sim$ half of the total applied in the rainfall), this would amount to a total sediment loss of $1024 \mathrm{~g}$. With an average TKP concentration of $0.94 \mathrm{mg} / \mathrm{g}$, a loss of $962.6 \mathrm{mg}$ per $200 \mathrm{~L}$ would occur in comparison to the total FRP amount of $408 \mathrm{mg}$ per $200 \mathrm{~L}$ (average FRP concentration of runoff $2.04 \mathrm{~g} / \mathrm{L} \mathrm{x} 200$ L). Likewise for a low sediment loss plot (SIP Plot $95 \mathrm{~m}$ buffer), a TKP loss of $7.2 \mathrm{mg}$ would occur in contrast to $5.4 \mathrm{mg}$ of FRP per $200 \mathrm{~L}$. Thus in this study, the sediment trapping efficiency of the buffer is likely to have a greater overall effect on the pollutant transport rather than reduced transport of soluble nutrients.

\section{Conclusion}

Under high intensity simulated rainfall, pasture buffer strips were very effective in forcing the deposition of influent sediments, including floating organic debris, from runoff following burning. ANOVA indicated that buffer length was significant for SLR, FRP, $\mathrm{NH}_{4}{ }^{+}, \mathrm{DOP}$ and TOC. A 2 m buffer strip was effective in removing much of the suspended sediments and soluble components except for $\mathrm{NO}_{\mathrm{X}}$. Increasing the buffer width to $5 \mathrm{~m}$ caused moderate decreases in SLR, but results were variable for the other parameters. Likewise, the ERs were decreased by $30-50 \%$ of their value within the first $2 \mathrm{~m}$ of the buffer and a further increase in buffer length only reduced ER marginally. The type of pasture (SIP versus FIP) was significant for four of the runoff parameters ( $\left.\mathrm{SLR}, \mathrm{NO}_{\mathrm{X}}, \mathrm{NH}_{4}^{+}, \mathrm{TOC}\right)$.

Data from this type of plot experiment provide a very useful comparison of burning treatment effects but they should be combined with spatial and temporal data at a larger catchment level to provide a more comprehensive understanding of contaminant transport following burning.

Within these limitations, our study suggests that strips of unburnt pasture grass offer a potential tool for post-fire erosion and pollutant transport control following prescribed 
burning. The width and location of such pasture strips would depend on the main aim of the buffer utilization. If the primary aim is to reduce the loss of sediment (including organic carbon, nitrogen and phosphorus), buffer conditions such as grass thickness and height might therefore be more important than infiltration characteristics which would affect loss of soluble components from the runoff.

\section{Acknowledgments}

The authors wish to acknowledge the support provided by the South East Queensland Water Corporation (SEQWater) for this project. Our special thanks and appreciation go to Miss Vourn Lutton, formerly of SEQWater for providing all the support and coordination that was needed for the successful completion of the field operations.

\section{References}

ANZECC, ARMCANZ (2000). Australian and New Zealand guidelines for fresh and marine water quality. Volume 1, Chapter 3. Aquatic Ecosystems, Canberra, Australia. Benavides-Solorio JD, MacDonald L, Hughes DJ (2004) Recovery of runoff and erosion rates after forest fires: An assessment using rainfall simulations. Geophysical Research Abstracts 6, 07737.

Blanco-Canqui H, Gantzer CJ, Anderson SH, Alberts EE, Thompson AL (2004) Grass barriers and vegetative filter strip effectiveness in reducing runoff, sediment, nitrogen and phosphorus loss. Soil Science Society of America Journal 68, 1670-1678.

Burke JM, Prepas EE, Pinder S (2005) Runoff and phosphorus export patterns in large forested watersheds on the western Canadian Boreal Plain before and for 4 years after wildfire. Journal of Environmental Engineering and Science 4, 319-325(7). 
Carreira JA, Xavier-Niell F, Lajtha K (1994) Soil nitrogen availability and nitrification in Mediterranean shrublands of varying fire history and successional stage. Biogeochemistry 26, 189-209.

Cerdia A, Bodi MB, Burguet M, Segura M, Jovani C (2009) The plot size effect on soil erosion on rainfed agriculture land under different land uses in eastern Spain. Geophysical Research Abstracts 11, 185.

Coelho COA, Ferreira AJD, Boulet AK, Keizer JJ. 2004. Overland flow generation processes, erosion yields and solute loss following different intensity fires, Quarterly Journal of Engineering Geology and Hydrogeology 37, 233-240.

Dabney SM, Meyer LD, Harmon WC, Alonso CV, Foster GR (1995) Depositional patterns of sediment trapped by grass hedges. Transactions of the ASAE 38, 1719-1729.

DeBano LF, Neary DG, Ffolliott PF (1998) Fire's effect on ecosystems. John Wiley \& Son, $352 \mathrm{pp}$.

Diamond D (1996) 'QuikChem Method 13-107-06-2-D - Determination of Total Kjeldahl Nitrogen in Soils and Plants by Flow Injection Analysis', Zellweger Analytics, Inc. Lachat Instruments Division, Milwaukee, USA.

Dragovich D, Morris R (2002) Fire intensity, runoff and sediment movement in Eucalypt forest near Sdney, Australia. In: Applied Geomorphology. ( Ed. R J Allison). Chapter 9. John Wiley \& Son.

Ferreira AJD, Coelho COA, Ritsema CJ, Boulet AK, Keizer JJ (2008) Soil and water degradation processes in burned areas: Lessons learned from a nested approach. Catena 74, 273-285.

Ghadiri H, Rose, CW (1991a) Sorbed chemical transport in overland flow. Part 1: An enrichment mechanism for sorbed nutrients and pesticides. Journal of Environmental Quality 20(3), 628-633. 
Ghadiri H, Rose CW (1991b) Sorbed chemical transport in overland flow. Part 2: Enrichment ratio of sorbed chemicals and its variation with time, particle size and erosion process. Journal of Environmental Quality 20(3), 634-641.

Ghadiri H, Rose CW, Hogarth WL (2001) The influence of grass and porous barrier strips on runoff hydrology and sediment transport. Transactions of ASAE, 44(2), 259-267.

Gharabaghi B, Rudra RP, Whiteley HR, Dickingson WT (2002) Development of a management tool for vegetative filter strips. In: Best modelling practices for urban water systems (Ed. W. James) Volume 10 in the monograph series: 289-302.

Healthy Waterways ( 2009) Healthy Waterways Complex Conceptual model 23: Wivenhoe Dam. (www.healthywaterways.org accessed on 17 April 2010)

Hudson NW (1993) Field measurement of soil erosion and runoff. FAO Soils Bulletin 68. Hussein J, Ghadiri H, Yu B, Rose CW ( 2007) Sediment Retention by a Stiff Grass Hedge under Subcritical Flow Conditions. Soil Science Society of America Journal 71, 1516 1523.

Hussein J, Ghadiri H, Lutton M, Smolders A, Schneider P (2008) The effect of flow impedance on deposition of Cryptosporidium parvum oocysts with or without a vetiver buffer strip. Soil Biology \& Biochemistry 40, 2696-2698.

Johansen MP, Hakonson TE, Breshears DD (2001) Post-fire runoff and erosion from rainfall simulation: Contrasting forests with shrublands and grasslands. Hydrological Processes 15, 2953-2965.

Lane PJ, Sherida GJ, Noske PJ (2006) Changes in sediment loads and discharge from small mountain catchments following wildfire in south eastern Australia. Journal of Hydrology 331, 495-510. 
Llovet J, Josa R, Vallejo VR (2008) Thermal shock and rain effects on soil surface characteristics. A laboratory approach. Catena 74, 227-234.

Loch RJ, Robotham BG, Zeller L, Masterman N, Orange DN, Bridge BJ, Sheridan G, Bourke JJ (2001) A multi-purpose rainfall simulator for field infiltration and erosion studies. Australian Journal of Soil Research 39, 600-610.

Malhi SS, McGill WB (1982) Nitrification in three Alberta soils: Effect of temperature, moisture and substrate concentration. Soil Biology \& Biochemistry 14, 393-399.

Marshall TJ, Holmes JW, Rose CW (1996) Soil Physics. (Third Edition). Cambridge University Press, Cambridge, UK.

Meyer LM, Dabney SM, Harmon WC (1995) Sediment trapping effectiveness of stiff grass hedges. Transactions of ASAE 38, 809-815.

Miller WW, Johnson DW, Loupe T M, Sedinger J S, Carroll E M, Murphy J D, Walker R , Glass D S (2006) Nutrient Flow from Runoff at Burned Forest Site in Lake Tahoe Basin. California Agriculture 60(2), 65-71.

Orr DM, Paton CJ (1997) Using fire to manage species composition in Heteropogon contortus (black speargrass) pastures. Australian Journal of Agricultural Research 48, 803-810.

Prosser IP, Williams L (1997) The effect of wildfire on runoff and erosion in native Eucalyptus forest. Hydrological Processes 12, 251-265.

Robichaud PR, Waldrop TA (1994) A comparison of surface runoff and sediment yields from low and high severity site preparation burns. Water Resources Bulletin 30, 27-34.

Rose CW, Parlange JY, Hogarth WL, Ghadiri H (2002) Overland flow to and through a segment of uniform resistance. Journal of Hydrology 255, 134-150. 
Rose CW, Yu B, Hogarth WL, Okom A, Ghadiri H (2003) Sediment deposition from flow at low gradients into a buffer strip- a critical test of re-entrainment theory. Journal of Hydrology 280, 33-51.

Rose CW, Yu B, Ghadiri H, Asadi H, Parlange JY, Hogarth WL, Hussein J. 2007. Dynamic erosion in steady sheet flow, Journal of Hydrology 333, 449-458.

Sander GC, Hairsine PB, Rose CW, Campbell SY, Barry DA (1996) Unsteady soil erosion model, analytical solutions and comparison with experimental results. Journal of Hydrology 178, 351-368.

Stange CF, Neue HU (2009) Seasonal variation of gross nitrification rates at three differently treated long-term fertilisation sites. Biogeoscience Discussions 6,1565-1598.

Svejcar TJ (1989) Animal performance and diet quality as influenced by burning tallgrass prairie. Journal of Range Management 42, 11-15.

Thomas AD, Walsh RP, Shakesby RA (1999) Nutrient losses in eroded sediment after fire in eucalytptus and pine forests in the wet Mediterranean environment of northern Portugal. Catena 36, 283-302.

Tran C, Gilroy J (2006 Fuel-load assessment at Mojoo Bay, Wivenhoe Dam. Report for South East Queensland Water Corporation. Brisbane, Australia

Wan S, Hui D, Luo Y (2001) Fire effects on nitrogen pools and dynamics in terrestrial ecosystems: a meta-analysis. Ecological Applications 11, 1349-1365.

Wohlgemuth PM. 2003. Post-Fire Erosion Control Research on the San Dimas Experimental Forest: Past and Present. In: First Interagency Conference on Research in the Watersheds, October 27-30, 2003. (Eds.) Renard, K. G., McElroy, S. A., Gburek, William J., Canfield, H., Scott, E., Russell L., U.S. Department of Agriculture, Agricultural Research Service 
